\title{
Where Do They Come From and How Can We Find More? Recruiting Teacher Candidates During Lean Times
}

Excelsior: Leadership in

Teaching and Learning 2018, Vol. 11(1) 41-53

(C) The Authors 2018 CC-BY 4.0 International Reprints and permissions: surface.syr.edu/excelsior https://doi.org/10.14305/jn.1

9440413.2018.11.1.04

nyacte.org

\section{Bruce Saddler ${ }^{1}$, Kirstie Asaro-Saddler ${ }^{1}$, Tammy Ellis-Robinson ${ }^{1}$, and Matthew LaFave ${ }^{1}$}

\begin{abstract}
Teacher preparation programs are facing an alarming drop in enrollments around the country. Our university, The State University of New York at Albany, has not been exempted from decreased enrollments. Low enrollments have led us to initiate direct attempts to recruit quality applicants to our master's programs. As part of our overall recruiting plan, we created a survey of our applicants to determine how they discovered our programs and why they want to attend our programs so that we can better utilize our limited advertising resources. Survey results and implications for recruiting teacher candidates are discussed.
\end{abstract}

\section{Keywords}

Teacher preparation

The reasons people enter the teaching profession are many and varied. Some may enter the field for altruistic or intrinsic reasons including their own personal characteristics, the opportunity to work with young people, the intellectual stimulation teaching can provide, or the chance to make an important contribution to society (Guarino, Sanibanez \& Daley, 2006). Others may be motivated by extrinsic factors such as compensation, working conditions, or work schedule. Although there are ample reasons for anyone to want to become a teacher, apparently those reasons have not been potent enough to attract pre-service teacher candidates in recent years.

At present, teacher preparation programs are facing an alarming drop in enrollments around the country. A lack of teacher candidates could fuel an eventual scarcity of qualified teachers entering the

\footnotetext{
1 University at Albany, State University of New York

Corresponding Author:

Bruce Saddler, Division of Special Education, School of Education, SUNY Albany, Education 231, 1400 Washington

Avenue, Albany, NY 12222.

Email: bsaddler@albany.edu
}

(c) (i) (8)

C 2018 Saddler, Bruce. This open access article is distributed under a Creative Commons Attribution 4.0 License (https://creativecommons.org/licenses/by/4.0/) 
teaching force. Fewer new teachers entering the field coupled with veteran teachers departing the field through occupational shifts or retirements is a recipe for chronic shortages, a scenario that is currently being realized not only in the United States but globally as well and had been foreshadowed years ago. For example, one estimate suggested that, as of 2016, primary schools around the world encountered a shortage of 18 million teachers, including a 13 million shortfall in teachers in low-income regions, and a further five million shortage in industrialized countries (Australian Associated Press, 2007). While it is difficult to verify those figures, the shortage of teachers in the United States can be confirmed.

Decreased enrollments in post baccalaureate programs and teacher preparation programs specifically are projected to result in a severe teacher shortage in the near future (US Department of Education, 2016). Recent data from ACT and the Department of Education indicate that "fewer high school graduates are interested in pursuing education majors and fewer college students are pursuing teaching careers" (Aragon, 2016, p. 2). This lack of interest in education is nothing new, as there has been a decreasing national trend over the last ten years in the number of education degrees as compared to the other top Masters granting fields (US. Department of Education, 2016). According to the most recent Title II National Teacher Preparation Data report, enrollments in teacher preparation programs have decreased from 683,903 candidates in 2010-2011 to 441,439 candidates in 2015-2016 (United States Department of Education, 2017). New York State has likewise experienced declining enrollments in teacher preparation programs. For example, 2012-2013 data indicate that New York State experienced an $11.85 \%$ decline from 70,218 to 61,821 over a five year period. In three years (20122013 to 2015-2016), the number of students enrolled in traditional teacher preparation programs decreased by an additional 6,000 students (United States Department of Education, 2017). The decline is most notable across specific fields of education, including science, math, and special education (New York State School Boards Association, 2017). These numbers are and should be alarming, since few issues in education threaten the well-being of our nation more than the growing shortage of teachers (Zhang \& Zeller, 2016).

Our university, The State University of New York at Albany (UAlbany), has not been exempted from these decreased enrollments. The School of Education experienced a $21.85 \%$ decline in teacher preparation enrollments from 2012-2013 to 2015-2016 (United States Department of Education, 2017). Within UAlbany, the Division of Special Education has also experienced declining enrollments. The Division of Special Education, which consists of five on-campus master's degree programs with five full-time faculty members, has historically overenrolled every year with waiting lists of qualified applicants. However, the total applications to our Master's degree programs has declined 58\% from a high of 187 in 2007 to 78 applications received in 2014. In 2017, the number of applications decreased to an all-time low of 34. This decrease in applications to our programs mirrors a general decline in the numbers of qualified teachers in the field of special education that was noted to have reached "epidemic" levels in all parts of the country as long ago as 2007 (Thornton, Peltier \& Medina, 2007).

There are several potential reasons for this declining enrollment trend of general and special education teachers. First, the birthrate has decreased to the lowest it has been in over thirty years (Hamilton, Martin, Osterman, Driscoll, \& Rossen, 2018). This trend was especially noted in the Northeast, in which UAlbany is located, and the Midwest (Kim, 2018). Fewer births means fewer students enrolling in schools, and thus fewer potential candidates to become teachers.

Second, there are continuing aggressive assaults on the quality of public schools in the media and perceptions of the current state of education (Mack, Smith, \& Norasing, 2003; Strauss, 2015). Scrutiny of the teaching profession and teacher preparation has arisen concurrently with, and as a result of, concerns about educational outcomes for America's students. According to recent reports on educational 
outcomes, U.S. students lag behind other nations and are lacking key skills and competencies needed to succeed in the $21^{\text {st }}$ century Global Marketplace (Walsh, 2013). Factors affecting academic outcomes are complex and varied, from poverty (Petrilli \& Wright, 2016) to parents' educational attainment; however, media reports have increasingly emphasized the teaching force as the culprit of the problem (Walsh, 2013; Walker, 2014). Since teachers have been identified as the single most important factor for the determination of student outcomes and adult success (e.g., Chetty, Friedman, \& Rockoff, 2014; Goldhaber, 2016), unfortunately, unsatisfactory student outcomes have been blamed on ineffective and ill-prepared teachers (McCleskey \& Ross, 2004). For the most recent group of individuals entering the field, the politicization and intense criticism of teachers has led to a tumultuous view of teaching careers as unfruitful and undesirable (Koenig, 2014; McCleskey \& Ross, 2004; Woods, Richards \& Ayers, 2016). In an examination of headlines in the New York Times related to teaching, Bohan (2016) reports that an emerging theme of the last fifteen years was that "...the United States has poor teachers and consequently needs better teachers..." (p.8).

Third, economic considerations could certainly have had a deleterious impact on potential teachers' attitude toward the profession as a viable career. Specifically, the affordability of the required degree and certification requirements, as well as the salary earned once in the field, coupled with an increasing number of lay-offs following the 2008 financial crisis (Aragon, 2016; Sawchuck, 2014; Barth, Dillon, Hull, \& Higgins, 2016; Podolsky, Kini, Bishop, Darling-Hammond, 2017). For example, recent additional New York State and National requirements for entry into (e.g. GRE) and for exit from (e.g. edTPA and certification exams) teacher preparation programs have not only made the process of becoming a teacher more rigorous, but also more expensive. In fact, costs for exams can be upwards of $\$ 1,000$ for initial teacher certification (Mattison, 2014) considering the edTPA (which alone costs $\$ 300$ as of Fall 2018), other exams, workshops, and fingerprinting, among other costs. Potential teachers may be dissuaded from entering the field if they perceive the cost to be greater than the possible rewards.

Fourth, alternative routes to teacher certification may draw off potential applicants (Clukey, 2016). Initially the motivation by state certification agencies to provide streamlined pathways for individuals who might be deterred by the extended process for licensure to enter the field was only in areas of great need, including STEM, special education, and teachers of culturally and linguistically diverse students. Now, however, an increasing number of options have arisen in other areas as well, including elementary areas, where shortages have not existed previously. These pathways exist as both a response to the mandate to provide more "highly qualified" teachers and the perceived shortage of teacher candidates.

Finally, a perceived lack of respect for teachers, declining morale, and lack of job satisfaction may lead to fewer potential teachers wanting to enter the field of education (United States Department of Education, 2013). A high number of educators who enter education report overall "job dissatisfaction, a loss of autonomy and limitations in feedback, recognition, advancement and reward" (Aragon, 2016, p.3). In large inner-city districts, exit interviews indicated that teachers leave the field primarily due to difficult working conditions and a lack of support (Saunders, 2017). In special education in particular, working conditions include teaching more subjects than their colleagues, not feeling supported, and lacking time and resources to do their jobs well (Samuels, 2016). Furthermore, there is a perception among special education teachers of low status and pay, and decreased motivation and discipline in students (Fish \& Stevens, 2010).

All of these factors undoubtedly contribute a cumulative, yet indeterminable, negative impact on our application pool. Due to our low rate of application submission and enrollments we have had to, for the first time in the history of the program at UAlbany, make direct attempts to recruit quality applicants to our master's programs. With recruitment being out of the realm of expertise for our faculty, and with 
limited resources available to help, our Division has had to devise a plan to attract and recruit qualified candidates to the programs. Since we believe that strong university teacher preparation programs produce educators who are better prepared and more likely to remain in the profession, it is in the best interest of the field and the students in need of quality teachers to promote entry into our programs. Since we are likely not alone in these beliefs, nor in the need to recruit quality applicants, the purpose of this article is to disseminate a recruiting tool we found useful, a prospective student survey, in order to assist other teacher preparation programs improve their own recruitment.

\section{Methods}

\section{Recruiting Plan}

Our overall recruiting scheme included actions such as visits to UAlbany student organizations and select undergrad classes to discuss our program, print advertisements detailing program benefits placed around campus, advertisements placed in student newspapers of other colleges and universities, information nights at local and regional conferences, and attendance at recruiting fairs. Although we believed our plan had potential, we had no proof that any of these avenues would help us reach qualified candidates. Therefore, we believed that a logical next step would be to ask prospective candidates how they found us. To do this we created a survey that was administered to each applicant who attended one of our spring interview days. During the interview days each potential applicant who has applied to our program is screened through the administration of a series of activities, including an interview with faculty, a math test, and a reading/writing task. We use all of these metrics along with undergraduate cumulative GPA, GRE, letters of recommendation, and a personal statement to decide on the qualifications of each applicant. Our survey became another activity that each applicant completed on interview day.

\section{The Survey}

We created our survey for several reasons: First, to determine how our applicants discovered our programs. This knowledge could help us spend our limited advertising resources on sources that have a better chance of yielding qualified applications. Second, to ascertain the reasons our applicants want to attend UAlbany. Third, to acquire additional information about our applicants including how they intend to fund their studies, and their career goals after graduation. Finally, we wanted to gain their impressions of our interview process so that we could improve future applicants' experience.

The survey instrument (see Figure 1) was designed to be a brief, 8-question probe that could be completed quickly and anonymously by applicants on interview day. The only identifier we asked applicants to complete was an acknowledgement of the program they applied to so that we could determine what differences existed between the applicants.

We asked each applicant to answer how he or she heard about our program. We offered several sources for them to choose from and included an "other" category for a source we did not list. This list of possible sources was created by our faculty after brainstorming all of the methods we used to discover the various colleges and universities that we had attended when we were selecting undergraduate and graduate schools to attend. In addition, we spoke to several graduate students in our department to ask how they located our University during their own search for a graduate program. From these discussions and brainstorming sessions, we arrived at a list of 12 potential "paths" future students might use to find us. 
As part of efforts to improve the special education graduate programs at the University at Albany, we are collecting information from prospective students that may be used to provide formative feedback to faculty and administrators about the current state of the application process, programs and prospective students. Please answer all the questions you feel comfortable answering and provide the answer that best reflects your status or opinion. Feel free to use additional space if necessary. We want to understand your responses. As a reminder, your participation is completely voluntary, your responses are strictly confidential and will not be released in any way that allows an individual to be identified. Only aggregate data will be presented in any reports. Thank you for participating in this survey!

1. What degree program did you apply to? Please place a check mark $(\checkmark)$ in the column next to your degree program name.

\begin{tabular}{|c|l|}
\hline$(\sqrt{ })$ & \multicolumn{1}{|c|}{ 冈 Degree Program } \\
\hline & M.S. in Special Education and Literacy (I) \\
\hline & M.S. in Special Education and Literacy (II) \\
\hline & M.S. in Special Education (Intern Cert) \\
\hline
\end{tabular}

2. How did you hear about the program? Please check $(\checkmark)$ all that apply and provide explanations if needed. If you check multiple sources, please use the rank column to number the sources in order of their usefulness to you with the number " 1 " representing the most useful.

\begin{tabular}{|c|c|c|c|}
\hline$(\sqrt{ })$ & Source & Explanation & Rank \\
\hline & Internet Search (indicate search engine) & (e.g. Google) & \\
\hline & $\begin{array}{l}\text { Website other than UAlbany (indicate } \\
\text { website) }\end{array}$ & (e.g. gradschools.com) & \\
\hline & UAlbany website & & \\
\hline & $\begin{array}{l}\text { From a family member or friend who } \\
\text { completed the program }\end{array}$ & & \\
\hline & School Fair (indicate where) & & \\
\hline & Social Media (indicate site) & (e.g. Facebook) & \\
\hline & $\begin{array}{l}\text { You continued from undergraduate } \\
\text { education at UAlbany }\end{array}$ & & \\
\hline & Academic Advisor (indicate where) & & \\
\hline & Faculty at UAlbany & & \\
\hline & $\begin{array}{l}\text { Faculty at another institution (indicate } \\
\text { where) }\end{array}$ & & \\
\hline & Magazine or Book Ranking List & (e.g. U.S. News \& World Report) & \\
\hline & Advertisement (indicate type) & (e.g. radio, tv, newspaper ad) & \\
\hline & Other (explain) & & \\
\hline
\end{tabular}

3. What other schools, if any, did you apply to for special education or literacy? 
4. What factor(s) do you consider most important in your decision to attend UAlbany? Please rank the following factors with " 1 " being the most important factor. If a factor is not relevant, you may leave it blank or put N/A to indicate it is not an important factor in your decision to attend UAlbany.

\begin{tabular}{|l|l|}
\hline Rank \# & Factors \\
\hline & Cost \\
\hline & Location \\
\hline & Program offerings (i.e. courses/field placements/experience) \\
\hline & Working with Faculty \\
\hline & Student life at UAlbany \\
\hline & Other (please explain) \\
\hline
\end{tabular}

5. How do you plan to fund your graduate studies? Please check $(\checkmark)$ all that apply. If you check multiple sources, please use the "Rank" column to indicate which source is the most significant with " 1 " being the most important source.

\begin{tabular}{|l|l|l|}
\hline$(\checkmark$ & Source & Rank \# \\
\hline & Money saved up & \\
\hline & Parental support & \\
\hline & Spousal/significant other support & \\
\hline & Working part-time (20 hours or less a week) & \\
\hline & Working full-time (more than 20 hours a week?) & \\
\hline & Student loans & \\
\hline & Other (please explain) & \\
\hline
\end{tabular}

6. If you were to attend UAlbany, what is your career goal after graduating? Please explain (e.g. teaching assistant in public school, continue on to get $\mathrm{PhD}$ in special ed, ESL teacher, etc.)

\begin{tabular}{|l|l|}
\hline Career Goal & Explanation \\
\hline Continue education & \\
\hline Seek full-time employment in education & \\
\hline Seek part-time employment in education & \\
\hline Seek employment outside of education & \\
\hline Other & \\
\hline
\end{tabular}

7. From what you know about us, what do you believe are the perceived strengths of the Special Education and Literacy programs?

8. In what ways do you think the application and interview process could be improved?

Figure 1. Division of Special Education - Prospective Student Survey

Next, we asked applicants to identify any other schools they had applied to so we could determine our chief competitors and what those programs or schools offer that perhaps we do not. We then asked what factors were most important in their decision to attend our programs, how they intend to fund their 
studies, their career goals after graduation, and what they believed were the perceived strengths of our programs. Finally, we asked how the application and interview process could be improved.

The survey has been administered at each of our interview days beginning in spring 2015 until our most recent interviews in spring 2017. A total of 99 applicants completed the survey with 45 from our two main programs, the Special Education and Literacy 1 program (SEL 1 - designed for applicants who hold an initial teacher certification in childhood education) and 54 for our Special Education and Literacy 2 program (SEL 2 - designed for applicants who do not have an initial childhood certification).

\section{Results}

Although the survey yielded a great deal of demographic characteristics about our applicants that we have found to be useful in our recruiting efforts by helping us describe the profile of our "typical" applicant to potential applicants, we are reporting survey results in three areas for this article that we believed would be the most valuable in improving our recruiting efforts, and therefore may be the most useful to other universities and programs: the Source that prompted the applicants to submit an application to our programs, the Factors that impacted the applicants' decision to apply to our programs, and the schools that applicants applied to, other than UAlbany.

Source. Data related to Source were tallied according to responses for each respective cohort and year. The first three responses for all of the SEL Is and first four responses for the SEL IIs were tallied. We used four responses for the SEL IIs because there were many applicants that provided more than three responses. The items most selected represent the categories in the data table. The percentage was calculated by taking the number of tallied responses per category, and dividing it by the total number of responses. Percentages were rounded up to the nearest whole number.

As can be seen in Table 1, the majority of our students in both of our programs (33\% and 36\% respectively) found us via our university website. The remaining students located us either by an internet search or family and friends in relatively equal numbers. Only a few others mentioned their undergraduate institution as a source of information. Students did not specifically mention social media websites.

Table 1

Responses and Percentages for Survey item SOURCE

\begin{tabular}{lrrrr}
\hline Cohort & Total I & $\%$ & Total II & $\%$ \\
\hline Responses & $\underline{92}$ & & $\underline{101}$ & \\
Internet Search & 23 & 25 & 13 & 13 \\
UALB Website & 30 & 33 & 26 & 36 \\
Friends/ Family & 23 & 25 & 15 & 15 \\
Undergrad Inst. & & & 13 & 13 \\
\hline
\end{tabular}

Factors. Data related to Factors were tallied according to responses for each respective cohort and year. The first four responses were tallied, and the items most selected represent the categories in the data table. Percentages were calculated by taking the number of tallied responses per category, and dividing it by the total number of responses. Percentages were rounded up to the nearest whole number. 
As can be seen in Table 2, both groups indicated that our program was the primary factor that persuaded them to submit an application. For the SEL Is the location of our program was a strong reason to apply whereas for the SEL IIs, working with faculty was important. Although cost was important to both groups, it was the least selected of the top four responses.

Table 2

Responses and Percentages for Survey item FACTORS

\begin{tabular}{lrrrr}
\hline Cohort & Total I & $\%$ & Total II & $\%$ \\
\hline Responses & $\underline{133}$ & & $\underline{156}$ & \\
Cost & 23 & 17 & 31 & 20 \\
Location & 36 & 27 & 33 & 21 \\
Program & 44 & 33 & 41 & 26 \\
Work w/Faculty & 26 & 20 & 40 & 26 \\
\hline
\end{tabular}

Schools. The percentage of schools to which the applicants applied, in terms of public or a private school, was calculated by taking the number of tallied responses per category and dividing it by the total number of responses. Percentages were rounded up to the nearest whole number.

As can be seen in Table 3, the large majority of students in both groups indicated that they had applied to private schools in addition to UAlbany. The number of schools to which students applied varied and ranged from one to as many as five other schools.

Table 3

Responses and Percentages for Survey item SCHOOLS

\begin{tabular}{lllll}
\hline Cohort & Total I & $\%$ & Total II & $\%$ \\
\hline Responses & $\underline{29}$ & & $\underline{38}$ & \\
\hline Public NY & 6 & 21 & 6 & 16 \\
Private NY & 21 & 72 & 30 & 79 \\
\hline
\end{tabular}

\section{Discussion}

Source. Before creating this survey, we believed that many of students likely found us through personal interactions with family members, friends, or former students who were aware of or who may have completed one of our programs. In addition, they could have learned about us at a college recruiting fair or through faculty either at our or at another institution. Finally, we believed that their academic advisor or counselor may have suggested our program.

Interestingly, although many of our students learned about us through family or friends, few students in the SEL II program and no students in the SEL I program indicated that their undergrad institution was a source of knowledge that made them aware of our program. This is an alarming finding to us as it means few students are learning about us through any existing informational channel (e.g., advising/counseling center, faculty advisor). Clearly we have work to do to spread the word about our programs to the appropriate offices and faculty at institutions around the state.

We were not surprised that the majority of students discovered us through electronic pathways, primarily our own UAlbany website, followed closely by an internet search of colleges/universities. Electronic pathways offer several possibilities in our minds. Many college age students are part of the 
current internet culture generation, also termed the millennials, who form a collection of smart, practical and techno-savvy people characterized by shared common life experiences (Lancaster \& Stillman, 2002) and who typically use the internet to research colleges (Mentz \& Whiteside, 2003). This is understandable since the internet offers easy access from home or a public space such as a library, requires less interaction with people, and offers instant answers to questions using Web navigation and FAQ links (Mentz \& Whiteside, 2003).

Although we were not surprised by this finding, it has raised concerns about the effectiveness of our current website as a recruiting tool. Our website represents our "front door," and clearly students are coming to us via that pathway; therefore, our website needs to be as comprehensive, easy to use, and visually pleasing as we can make it. Currently we are considering major structural and cosmetic changes to our site to improve its utility and appeal. In addition, we were somewhat surprised that students did not use social media resources to locate our program. This has prompted us to revisit our use of social media as a potential means of advertising our programs.

We were most concerned that print media was not selected as source. Given that some college students still indicate a preference for print newspapers (e.g., Qayyum, Williamson, Liu, \& Hider, 2010) we invested significant amounts of money in the last three years advertising in universities and colleges that have a campus paper and that we knew our former students had attended. In addition, we advertised at institutions we would consider likely sources of applicants; however, it appears that our time and money was not well spent.

Factors. We were very pleased that both groups indicated that our program was the primary factor that persuaded them to submit an application. We believe we have a unique program that well-prepares teachers for the rigors of our profession, and this finding seemed to validate our efforts. Specific comments from applicants included "real world experience through multiple practicum/internships" "offering special education and literacy classes together will make for a more well-rounded and skilled educator," "small program with close-knit staff" and "program has a great national reputation and public school affordability." Interestingly, although cost was important to both groups, it was the least selected of the top four responses. We had believed that cost would be first on most students' minds since we are a public state-supported institution with relatively low tuition costs.

Schools. We were not surprised that most of our students applied to private institutions in addition to UAlbany because there are several other private institutions in our geographical area that offer similar programs to our own. Given that the SEL 1 group in particular identified our location as being an important factor, it would make sense that they would apply to other private schools in our region. To us, this finding confirmed who our local competition is, and how we can improve our literature to highlight the differences between our programs and theirs. On the other hand, given that a large number of our students over the past three years have come from other State University of New York (SUNY) colleges and universities, we anticipated that they may apply to other SUNY schools as well. Therefore, the low percentage of public colleges was surprising.

\section{What can teacher preparation programs do?}

Although addressing the teacher shortage likely will require systemic change at the state and federal levels, teacher preparation programs may have a role to play in increasing the number of teacher 
candidates. First, we can promote the field of education in a positive light and help potential teachers understand all aspects of the job. Having events such as information sessions or attending high school career days may provide an opportunity to introduce the field of education and the benefits of becoming a teacher. Teacher preparation programs could also communicate with the state and local districts to determine their needs and to help prepare students to work in those areas. As Will (2018) reports, the areas in which teacher candidates major (such as elementary education) are often not the areas in which there is a need. University personnel can help by providing data on anticipated openings and shortages to students as they are selecting their majors (Will, 2018). Finally, schools of education can help provide supports in the form of scholarships, stipend, or other incentives. For the past two years at UAlbany, for example, we have been able to offer vouchers for one teacher certification exam for several high performing and needy students each year. Such incentives can help reduce the financial burden faced by future teachers.

\section{Conclusion}

We believe that our survey yielded important information for our program that have improved our recruiting scheme. We should note that the survey was never intended as a statistically rigorous instrument, and we have not proven its validity. Instead it is purely informational and we believe well suited for the purposes we intend. Future researchers may wish to develop the validity and reliability of such an instrument to be used for more stringent research purposes

We are well aware that any effort we make may not improve the amount of applications we receive; however, we believe that through continually refining our efforts and by gaining information about our applicants through this survey, we could eventually increase the quantity and quality of our applicant pool. But we are mindful that attracting motivated and intelligent candidates into any pre-service preparation program may require societal shifts in the value placed on teaching as a profession.

\section{Declaration of Conflicting Interests}

The authors declared no potential conflicts of interest with respect to the research, authorship, and/or publication of this article.

\section{Funding}

The authors received no financial support for this research.

\section{References}

Aragon, S. (2016). Teacher shortages: What we know. Teacher Shortage Series. Education Commission of the States. Retrieved from http://www.ecs.org/wp-content/uploads/TeacherShortages-What-We-Know.pdf.

Australian Associated Press (2007). World shortage of $18 m$ teachers by 2016. The Age.

Retrieved from http://www.theage.com.au/news/National/World-shortage-of-18m-teachersby-2016/2007/01/16/1168709745938.html.

Barth, P., Dillon, N., Hull, J., \& Higgins, B. (2016). Fixing the holes in the teacher pipeline: An overview of teacher shortages . Center for Public Education. Retrieved from http://www.centerforpubliceducation.org/system/files/Teacher\%20Shortage 0.pdf. 
Bohan, C. H. (2016). Presidential address: The past, present, and future of teaching and teacher education curriculum. Curriculum and Teaching Dialogue, 18(1/2), 3-12.

Chetty, R., Friedman, J. N., \& Rockoff, J. E. (2014). Measuring the impacts of teachers II: Teacher value-added and student outcomes in adulthood. American Economic Review, 104(9), 2633-2679. https://doi.org/10.1257/aer.104.9.2633

Clukey, K. (2016). As shortage looms, state rethinks how it recruits and treats its teachers. Politico. Retrieved from http://www.politico.com/states/new-york/albany/story/2016/03/asshortage-looms-state-rethinks-how-it-recruits-and-treats-its-teachers-032004

Fish, W. W. \& Stephens, T. L. (2010). Special education: A career of choice. Remedial and Special Education 31(5).400-407. https://doi.org/10.1177/0741932509355961

Goldhaber, D. (2016). In schools, teacher quality matters most. Education Next, 16, 56-62.

Guarino, C., Santibañez, L., \& Daley, G. (2006). Teacher recruitment and retention: A review of the recent empirical literature. Review of Educational Research, 76(2), 173-208.

https://doi.org/10.3102/00346543076002173

Hamilton, B. E., Martin J. A., Osterman, M.J. K., Driscoll, A. K., \& Rossen, L. M. (2018). Births: Provisional data for 2017. Vital Statistics Rapid Release No. 4. Hyattsville, MD: National Center for Health Statistics. Retrieved from:

https://www.cdc.gov/nchs/data/vsrr/report004.pdf.

Kim, J. (2018). Higher education leaders and the falling total fertility rate. Inside Higher Ed.

Retrieved from https://www.insidehighered.com/blogs/technology-and-learning/highereducation-leaders-and-falling-total-fertility-rate

Koenig, R (2014). Education degree programs, once popular, take a nosedive. The Chronicle of Higher Education. Retrieved from http://chronicle.com/article/Education-Degree-Programs/149277/.

Lancaster, L., \& Stillman, D. (2002). When generations collide. New York: Harper-Collins.

Mack, F.R-P.; Smith, V.G. \& Norasing, V. (2003, January). African American honor students' perceptions of teacher education as a career choice. Paper presented at the Annual Meeting of the American Association of Colleges for Teacher Education, New Orleans, LA.

Mattison, K. L. (2014). Unions to SED: Get it right. The Voice, 42, 4-5.

McLeskey, J. \& Ross, D. D. (2004). The politics of teacher education in the new millennium: Implications for special education teacher educators. Teacher Education and Special Education, 27(4), 342-349. https://doi.org/10.1177/088840640402700402

Mentz, G., \& Whiteside, R. (2003). Internet college recruiting and marketing: Web promotion, techniques and law. Journal of College Admission, 181, 10-17.

New York State School Boards Association. (2017). Teacher shortage? What teacher shortage? Retrieved from https://www.nyssba.org/clientuploads/nyssba_pdf/teacher-shortage-report05232017.pdf.

Petrilli, M. J., \& Wright, B. L. (2016). America's mediocre test scores: Education crisis or poverty crisis? Education Next, 16, 46-52.

Podolsky, A., Kini, T., Bishop, J., \& Darling-Hammond, L. (2017). Sticky schools: How to find and keep teachers in the classroom. Phi Delta Kappan, 98(8), 19-25.

https://doi.org/10.1177/0031721717708290 
Qayyum, M. A., Williamson, K., Liu, Y., \& Hider, P. (2010). Investigating the news seeking behavior of young adults. Australian Academic \& Research Libraries, 41(3), 178-191. https://doi.org/10.1177/0031721717708290

Samuels, C. A. (2016, Jan/Feb). Colleges seek out future special education teachers. Retrieved from https://www.edweek.org/ew/articles/2016/01/27/colleges-seek-out-future-special-edteachers.html

Saunders, S. (2017). Danger ahead: Severe teacher shortage looms for New York State. NYSUT United, $7(5), 14-15$.

Sawchuk, S. (2014). Steep drops seen in teacher-prep enrollment numbers. Education Week, 34, 1, 10.

Strauss, V. (2015, November 20). Why today's college students don't want to be teachers. Washington Post. Retrieved from https://www.washingtonpost.com/news/answersheet/wp/2015/11/20/why-todays-collegestudents-dont-want-to-be-teachers/?utm term $=. \mathrm{dc} 7 \mathrm{dd} 34 \mathrm{fb} 8 \mathrm{bf}$

Thornton, B., Peltier, G., \& Medina, R. (2007). Reducing the special education teacher shortage. Clearing House: A Journal of Educational Strategies, Issues and Ideas, 80(5), 233238. https://doi.org/10.3200/TCHS.80.5.233-238

United States Department of Education. (2016). Post-secondary education: Programs, courses and completions. The Condition of Education. Retrieved from https://nces.ed.gov/programs/coe/indicator ctb.asp.

United States Department of Education (2017). Title II reports. National Teacher Preparation Data. Retrieved from https://title2.ed.gov/Public/Home.aspx.

Walker, T. (September 22, 2014). The long history of blaming teachers first. NEA Today. Retrieved from http://neatoday.org/2014/09/22/the-long-history-of-blaming-teachers-first/.

Walsh, K. (2013). Teacher education: Ed schools don't give teachers the tools they need. Education Next, 13(3), 18-24.

Will, M. (2018). With declining enrollments, teacher colleges recalibrate. Education Week, 38(1), 6.

Woods, A. M., Richards, K. A. R., \& Ayers, S. F. (2016). All in: Teachers' and college faculty's roles in recruiting future physical educators. Journal of Physical Education, Recreation, and Dance, 87(4), 18-23. https://doi.org/10.1080/07303084.2016.1141731

Zhang, G., \& Zeller, N. (2016). A longitudinal investigation of the relationship between teacher preparation and teacher retention. Teacher Education Quarterly, 43(2), 73-92. 